\title{
Contributions of Annual Phenological Intensity to the Production of Tannins in Sideroxylon obtusifolium in Brazilian Semi-arid
}

\author{
Azenate Campos Gomes ${ }^{1}$ \\ Fabrício Havy Dantas de Andrade ${ }^{1}$ \\ Alecksandra Vieira de Lacerda ${ }^{2}$ (1) \\ Rui Oliveira Macêdo ${ }^{1}$ (D)
}

${ }^{1}$ Universidade Federal da Paraíba, Instituto de Pesquisa em Fármacos e Medicamentos, Centro de Ciências da Saúde, Departamento de Ciências Farmacêuticas, Joao Pessoa, PB, Brasil

${ }^{2}$ Universidade Federal de Campina Grande, Centro de Desenvolvimento Sustentável do Semiárido, Unidade Acadêmica de Tecnologia do Desenvolvimento, Laboratório de Ecologia e Botânica, Sumé, PB, Brasil

\begin{abstract}
The correlation between biological and ecological parameters is essential for the sustainable use of species. This study aimed to assess the relationship between phenological intensity and tannin production in Sideroxylon obtusifolium (Roem. \& Schult.) T.D.Penn. in environments with different precipitation regimes. The tannin production and phenological characterization were assessed through the intensity and synchrony of leaves, flower buds, flowers, and fruits in specimens from two microregions of Paraíba, northeastern Brazil. The specimens in the municipality of Sumé were not synchronous and fruiting is the least synchronous phenophase, with an index of only 0.17 . The specimens in São João do Cariri had synchronization of $0.77,0.82$, and 0.92 for flower bud, flowering, and fruiting phenophases, respectively. The correlation and factorial clustering showed that fruiting has a correlation of -0.75 with the production of tannins, suggesting that low intensity of annual fruiting is necessary for higher tannin production.
\end{abstract}

Keywords: Reproductive phenology, synchrony, secondary metabolites, Caatinga

\section{INTRODUCTION}

Sideroxylon obtusifolium (Roemer \& Schultes) T.D.Penn. belongs to the family Sapotaceae and is popularly known in Brazil as quixabeira, sapotiaba, sacutiaba, coronilha, coca, maçaranduba-da-praia, miri, and rompe-gibão. It is a deciduous or semi-deciduous spinescent tree, with a dense top and simple chartaceous and glabrous leaves, bright on the upper side. This species has inflorescences in axillary fascicles, with $2-20$ whitish, fragrant, and discreet flowers. It has drupe-type fruits, smooth, with sweet juicy pulp (Carneiro et al., 2015; Silva \& Dantas 2017).

S. obtusifolium has a wide geographical distribution, occurring in the Caatinga, Cerrado, Atlantic Forest, and Pantanal phytogeographic domains (Carneiro et al., 2015). In the Caatinga, Reséndiz (2018) and Lacerda \& Barbosa (2018, 2020) highlighted this species among those with a preference for more humid environments. Due to the wide distribution, flowering and fruiting periods vary in this species according to the environment (Barbosa et al., 1989, 2003; Gomes et al., 2010; Gomes et al., 2021; Kill et al., 2014). According to Kiill et al. (2014), the differences in phenological behavior, floral biology, and pollinating agents indicate climatic variables as one of the several factors capable of influencing this relationship.

Concerning the chemical constitution of S. obtusifolium, tannins are characterized as one of the main responsible for the high medicinal potential of adult specimens. However, many variations have been found in several studies. Thus, it is necessary to understand the metabolism processes throughout this species life cycle, which are constantly changing. The high variability in the active constituents of plants can put the patient's health and safety at risk; therefore, quality control is extremely necessary to ensure both the chemical composition of extracts and their safety use (Kicel et al., 2020).

Phenology is the study of the frequency, intensity, and synchronism of life cycle events, the causes of their occurrence in relation to the selective biotic and abiotic forces, as well as 
the interrelation between the phases characterized by these events in one or in different species (Alencar, 1979; Augspurger, 1983; Melo \& Carneiro, 2021; Rathcke \& Lacey, 1985). It is one of the most important lines of ecological research for being one of the best parameters for characterizing ecosystems (Lieth \& Schultz, 1974; koebsch et al., 2020). In addition, the changes expressed in each phenophase are a consequence of the whole process, which involves primary and secondary metabolites in the plants.

Given the above, this study aimed to assess the relationship between phenological intensity and tannin production in $S$. obtusifolium in environments with different precipitation regimes.

\section{MATERIAL AND METHODS}

\subsection{Study area}

This research was conducted in the Cariri region of Paraiba (northeastern Brazil), located on the western fringe of the Borborema Plateau, particularly in the central region, in the state of Paraíba. This region is characterized by a sudden transition from the rainy to the dry season and vice versa, as well as by the interannual regime, whose irregularity or year-to-year variability in rainfall totals has a very dispersed temporal distribution (Alves, 2009). According to the Köeppen classification, the region has a semi-arid (BSh) climate, with rainfall concentrated in three months of the year and the occurrence of high temperatures.

Despite the proximity between "Cariri Eastern" and "Cariri Western" microregions, it is worth mentioning their distinct edaphoclimatic characteristics, which substantially interfere with the vegetation behavior. This study was carried out specifically in the "Umburana" stream ( $745^{\prime} 15.3^{\prime}$ " S and $36^{\circ} 58^{\prime} 01.6^{\prime \prime} \mathrm{W} ; 571 \mathrm{~m}$ altitude), in the municipality of Sumé (Cariri Western), and in the "Gangorra" stream $\left(7^{\circ} 25^{\prime} 15^{\prime}\right.$ " S and $36^{\circ} 29^{\prime} 17^{\prime \prime}$ W; $460 \mathrm{~m}$ altitude), in the municipality of São João do Cariri (Cariri Eastern). Both areas are remnant conserved riparian forest in the Cariri region of Paraiba (Farias et al., 2017; Lacerda \& Barbosa, 2018, 2020). São João do Cariri had a historical annual average rainfall of $410.6 \mathrm{~mm}$ between 1911 and 2010 (Medeiros, 2015). Sumé has an annual rainfall of 540 $\mathrm{mm}$, according to data from a historical series, considering the period from 1930 to 1994 (Aesa, 2018).

\subsection{Data collection and analysis}

\subsubsection{Phenology}

Fifteen adult specimens of S. obtusifolium were sampled in each municipality. These specimens were assessed monthly over a year, from October 2016 to September 2017, in Sumé, and from October 2017 to September 2018, in São João do Cariri. The occurrence of phenophases was analyzed from direct observation of the trees' canopies, recording the presence or absence of leaves, budding, flower buds, flowers, and fruits.

The flowering period was divided into flower bud and anthesis and the fruiting period into unripe and ripe fruits (Mariano et al., 2016). The monitoring of each phenophase was recorded based on a quantitative scale ranging from of 0 to 4 whith interval of $25 \%$ between each category for estimating the percentage of phenophase intensity in each individual. In each month, the sum of the intensity values obtained for all individuals is made and divided by the maximum possible value (number of individuals multiplied by four). The obtained value was then multiplied by 100 , to turn it into a percentage value (Fournier, 1974).

The activity index (synchrony) was applied, which considers the presence or absence of phenophase. However, at a population level, this index has a quantitative character, indicating the percentage of specimens in the population that are manifesting a certain phenological event. This method was used to estimate the synchrony between the specimens in Sumé and São João do Cariri, considering that the greater the number of units undergoing the phenophase at the same time, the greater the synchrony of the population. The Augspurger (1983) method was used based on the equation 1:

$\mathrm{xi}=\left(1 / \mathrm{fi}^{*}(\mathrm{n}-1)\right)^{*}(\mathrm{eij})$

Where $\mathrm{xi}=$ Synchrony; $\mathrm{fi}=$ number of months an individual manifested the phenophase; $\mathrm{n}=$ total number of individuals that underwent the phenophase; $\mathrm{eij}=$ number of months in which an individual had the same phenophase simultaneously with the others

The exsiccates of the analyzed specimens were deposited in the Plant Collection of the Ecology and Botany Laboratory of the Center for Sustainable Development of the Semi-Arid (CDSA), Federal University of Campina Grande (UFCG), in the municipality of Sumé, Paraíba State.

The percentage of phenophases was calculated to describe the phenological patterns of the population, which was related to precipitation.

The climatological data of Sumé were obtained from the AESA, by the meteorological station of this municipality, located in the CDSA/UFCG. In São João do Cariri, the data were collected from the Escola Basin, belonging to the Federal University of Paraíba located in this municipality. 


\subsubsection{Extraction, preparation, and reading of solutions}

The aerial part of the analyzed trees was ground in a knife mill and subjected to sifting to obtain plant drug with particle sizes $\geq 37 \mu \mathrm{m}$. The extract was prepared using a mechanical stirrer (IKA RW 20) at $720 \mathrm{~Hz} / \mathrm{min}$ for 10 minutes, in a $50 \%$ hydroalcoholic solution at $0.03 \mathrm{~g} / \mathrm{ml}$ concentration. The samples were filtered using filter paper and a vacuum pump. The sample volume was then completed in a 50 -ml flask, from which a $1.5 \mathrm{ml}$ aliquot was separated and diluted in a $10-\mathrm{ml}$ flask. To verify the repeatability of the method, three plant drug extractions were performed for each type of analysis.

\subsubsection{Quantification of tannins}

The tannin content was determined by the vanillin-HCL method (Makkar \& Becker, 1993), by which a 0.4-ml sample from the aerial part of the specimens was added to $1.5 \mathrm{ml}$ of $4 \%$ vanillin solution, initially diluted in methanol and then diluted again in $\mathrm{HCl} \mathrm{PA} \mathrm{(37 \% ).} \mathrm{Before} \mathrm{the} \mathrm{reaction,} \mathrm{the}$ vanillin- $\mathrm{HCl}$ solution was subjected to cooling at $20^{\circ} \mathrm{C}$. The standard stock solution was obtained by dissolving $0.2655 \mathrm{~g}$ of hydrated catechin (Sigma) in $50 \mathrm{ml}$ of methanol. From this solution, the dilutions necessary for validation were performed.

Nine repetitions were performed (3 for each extract) during the quantification process. The reaction occurs in test tubes for 20 minutes, obtaining a final volume of $3 \mathrm{ml}$. The reading was performed at $500 \mathrm{~nm}$ against a blank composed of vanillin- $\mathrm{HCl}$ solution and hydroalcoholic solution. A visible ultraviolet spectrophotometer was used. The concentration of tannins was expressed as milligrams equivalent to catechin.

\subsubsection{Statistical analysis}

In the evaluation of biological parameters and quantification tannins, the Tukey test at $5 \%$ probability was used as a multiple comparison. Spearman correlation was applied to assess the correlation between precipitation and phenophases. Due to the large number of parameters used, in the development of the analytical method, multivariate analysis was applied through factor analysis by principal factors and correlation matrix with the use of the statistical software Action Stat 3.6 (2019).

\section{RESULTS AND DISCUSSION}

The phenological behavior of specimens of S. obtusifolium in the municipality of Sumé differed significantly from those in the municipality of São João do Cariri. The specimens selected for the phenological study in Sumé had an average diameter at ground level of $1.30 \mathrm{~m} \pm 0.6$ and an average height of $8.8 \mathrm{~m}$ \pm 0.7 . The specimens from São João do Cariri were classified with height and diameter of $6.5 \mathrm{~m} \pm 1.5$ and $0.54 \mathrm{~m} \pm 0.2$ respectively, thus being classified as individuals belonging to an adult population, as they have DGL $>0.3 \mathrm{~m}$ and height $>1.0 \mathrm{~m}$ (Rodal et al., 2013; Lacerda \& Barbosa, 2018). Precipitation and edaphic conditions are factors that significantly influence the difference in these development parameters, since both selected areas are plant communities of conserved riparian forest, these structural characteristics being the natural conditions of the specimens from each environment.

In the comparative study of the two studied environments, it was observed that, in general, there is no total rainfall pattern for the impulse and complet of the cycle of each $S$. obtusifolium phenophases, due to the specific adaptation of each specimen according to the environment in which it is located. In the municipality of São João do Cariri, annual rainfall of $155.22 \mathrm{~mm}$ was recorded, and the Fournier intensity ranged from $0-92.8 \%$, with the completion of cycles for all phenophases (Figure 1F-J). In Sumé the annual precipitation was $239.2 \mathrm{~mm}$, however, the Fournier intensity ranged from 0 to $53 \%$ (Figure $1 \mathrm{~A}-\mathrm{E}$ ), with an intensity of only $11.6 \%$ for the fruiting phenophase, followed by total abortion before the maturation stage (Figure 1E). In both municipalities, rainfall values were below the historical average of $500.1 \mathrm{~mm}$ and 468.7 mm, for Sumé and São João do Cariri, respectively. However, the monthly rainfall distribution of each environment is of great relevance for the maintenance and implementation of some phenophases according to their environment.

In Sumé, S. obtusifolium leaves were produced from April to July, ranging from 75.0 to $86.6 \%$, with a significant leaf fall in December (45\%), and deciduous process lasting from September to February (Figure 1A). In São João do Cariri, the vegetative phase had a peak between January and August, ranging from 75.0 to $85.7 \%$, with leaf fall in November and December, according to the Fournier intensity (Figure 1F).

In the Sumé municipality, flower budding occurred from January to August and flowering from January to July. It is noteworthy that, only after four consecutive months of rainfall between 17 and $87 \mathrm{~mm}$, Fournier intensity increased from 15 to $53.3 \%$ in July, when it reached the peak of flower budding. Flowering was little driven by rain, going from $21.6 \%$ to $25 \%$ after the highest monthly rainfall, in a year, i.e., $87 \mathrm{~mm}$ in March. However, all flowers aborted in the following month, and the specimens started to bloom again in May, with a peak of $25 \%$ in July, after four consecutive rainy months (Figure 1B, C). The flower budding and flowering, in São João do Cariri municipality, lasted throughout the year with a peak ranging from 57.1 to $71.4 \%$ and 71.4 to $89.2 \%$, respectively, between November and February, after which, these values decreased and started to increase in June, ranging from 14.2 
to $28.7 \%$ of flower buds, until October, and from 25 to $28.5 \%$ of flowering, until September (Figure 1G, H).

The fruiting in S. obtusifolium, in the municipality of Sumé, occurred only in February (8.3\%) and March (11.6\%); however, all fruits aborted when still unripe (Figure 1D, E). The specimens in São João do Cariri produced fruits between January and May, and the greatest intensity (92.8\%) for this phenophase was recorded in January and February. The highest dispersion of fruits was recorded in May because of their optimum ripening stage and period of three months for the completion of their cycle.
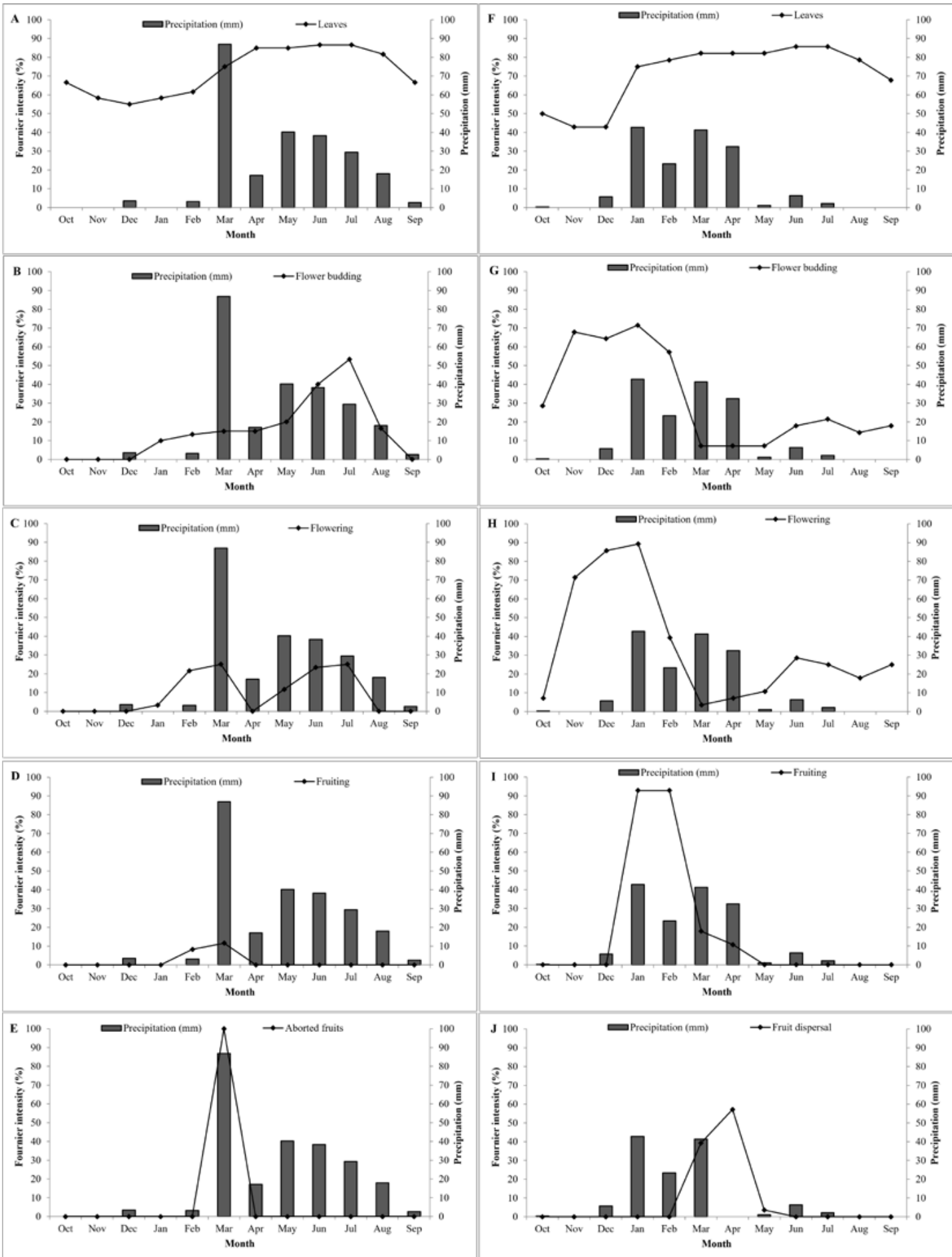

Figure 1. Phenological behavior of Sideroxylon obtusifolium based on Fournier intensity and rainfall in the municipalities of Sumé (A, B, C, D, E) and São João do Cariri (F, G, H, I, J) 
According to Spearman correlation, rainfall in Sumé showed a significant positive correlation with leaf production $\left(r_{s}=0.71 ; \mathrm{P}=0.01\right)$, flower buds $\left(r_{s}=0.79 ; \mathrm{P}=0.002\right)$ and with flowering $\left(r_{s}=0.63 ; P=0.03\right.$. São João do Cariri presented a different behavior since precipitation only showed a positive correlation with fruiting $\left(\mathrm{r}_{\mathrm{s}}=0.81 ; \mathrm{P}=0.001\right)$ and with dispersion of fruits $\left(r_{s}=0.59 ; \mathrm{P}=0.04\right)$. The data show different water content requirements for each phenophase of the specimens according to the environment. However, it is noteworthy that although Sumé had more parameters correlated with rainfall, which was also higher than that of São João do Cariri, the specimens from Sumé, in addition to having less phenological intensity, were unable to complete the reproductive cycle due to the abortion of the fruits.

Souza et al (2014), studying the phenology of six native tree species in a conserved area in the caatinga, observed that all species showed a positive correlation between precipitation and the formation of new leaves. Among the species studied, only Poincianella pyramidalis (Tul.) L.P. Queiroz (Fabaceae) and Manihot pseudoglaziovii Pax \& K. Hoffm. (Euphorbiaceae) showed a significant correlation between precipitation and flowering. These species together with Handroanthus heptaphyllus (Vell.) Mattos (Bignoniaceae) also showed a positive correlation between fruiting and precipitation.

Phenological and ecological studies on the genus Sideroxylon and of Sapotaceae family are few reported in the literature. Thus, there is little information on the phenological behavior of S. obtusifolium and its relationship with biotic and abiotic factors. The information recorded so far shows a high variation in this species phenophases in the different Brazilian biomes.

In the municipality of Alagoinha (Pernambuco, Brazil), flowering in S. obtusifolium was recorded in the rainy season, when fruits were also produced, and the formation of new leaves occurred in the transition from the rainy to the dry season (Barbosa et al., 2003). In the sand bar of "Maricá" (Rio de Janeiro), Gomes et al. (2010) recorded an annual pattern of reproductive phenophases, with a significant positive correlation between flowering and fruiting with abiotic factors. These authors also observed that $70.1 \%$ of the fruits were aborted.

Batalha \& Martins (2004), relating fruit ripening with these factors in the rainy season, observed this is common in zoochoric tree species in seasonal environments, as at this time the fruits remain attractive for a longer time, favoring the dispersion of seeds.

Flowering in the dry season seems to be a reproductive strategy for tree species in tropical forests, since the intense rainy season in these forests would result in the destruction of flower structure in species that have tiny and fragile flowers (Nieves et al., 2017; Silva et al., 2020), such as S. obtusifolium.

According to Alencar (1994), water availability is a fundamental element for fruiting in species of the family Sapotaceae, which are characterized by the presence of fleshy fruits. The rainfall below the historical average value may have influenced the low fruiting and total abortion of fruits in the municipality of Sumé; however, this behavior was not observed in fruits of specimens in São João do Cariri, where there was also a rainfall index below the historical average. A high rate of fruit abortion in Sapotaceae was recorded in Pouteria venosa (Mart.) Baehni and Manilkara subsericea (Mart.) Dubard (Gomes et al., 2008). Gomes et al., (2010) recorded $70.01 \%$ of aborted fruits in S. obtusifolium in an area of riparian forest, in Maricá (Rio de Janeiro, Brazil).

Kiill et al. (2014) explain that variations in the flowering and fruiting pattern of S. obtusifolium in different environments may be related to the climatic conditions of each region. These authors also report that the greater production of fruits in this species is due to cross-pollination by Apis mellifera and Diptera species. Thus, pollinators of this species may also have been affected by the water deficit in the municipality of Sumé, possibly reducing the population and, consequently, the pollination of flowers.

Several authors have mentioned that the phenological cycles of tropical plants are complex, presenting irregular patterns of difficult inference, mainly in short-term studies (Mariano et al., 2016; Suepa et al., 2016; Sakai \& Kitajima, 2019). According to Kiil et al. (2014), differences in phenological behavior, floral biology, and pollinating agents of S. obtusifolium indicate climatic variables as one of several factors capable of influencing this relationship.

In general, the data for fruiting corroborate with Silva et al. (2020) who reported that in the caatinga area S. obtusifolium fruited mainly during the rainy season, presenting high seasonality, with the highest fruiting frequencies between December and March, and a fruiting peak in February. The authors observed that, just like S. obtusifolium, the species Cissus sp., Cynophalla flexuosa (L.) J.Presl and Phoradendron quadrangulare (Kunth) Griseb. no presented in relationships between fruiting and monthly rainfall intensity.

The synchrony index of S. obtusifolium showed that the specimens in Sumé are not synchronous regarding flowering and fruiting stages and that fruiting phenophase is the least synchronous, with an index of only 0.17 . On the other hand, in São João do Cariri, the specimens showed high synchrony values in all assessed reproductive phenophases, which had a growing synchronization, with rates of $0.77,0.82$, and 0.92 for flower buds, flowering, and fruiting, respectively (Figure 2). 


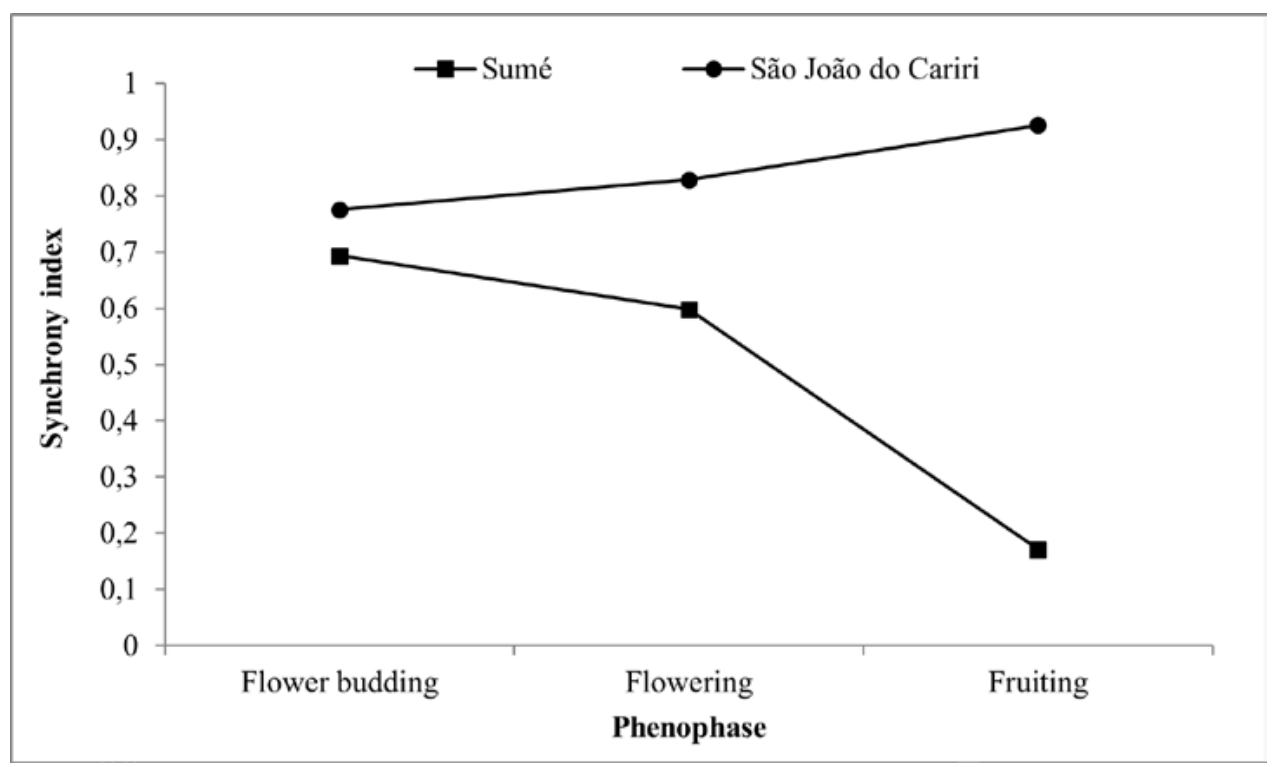

Figure 2. Synchrony index in the reproductive period of Sideroxylon obtusifolium, in the municipalities of Sumé and São João do Cariri (Semi-arid Brazil)

Phenological studies by Freitas et al. (2015), in the Brazilian Amazon, showed that Manilkara paraensis (Sapotaceae) has high flowering synchrony $(Z=0.75)$, with perfect synchrony in a single specimen and high synchrony in the population. Concerning fruiting phenophase, specimens of $M$. paraensis had high synchrony $(Z=0.90)$, with no perfect synchrony considering a single specimen, but with high synchrony between them, differently from what was observed in our research.

The low rate of synchrony in the reproductive stage, recorded when comparing the specimens in São João do Cariri, is a strong indication that the specimens in the "Umburana" stream, in Sumé, are less adapted to changes in biotic, abiotic factors and of their interactions, as the an effect of rainfall below the historical average on vegetation.

The data showed that regarding the concentration of tannins produced by the evaluated specimens, the two areas significantly differed from each other, with emphasis on the municipality of Sumé where the concentration was $64.38 \mathrm{mg} / \mathrm{g}$, whereas, in São João do Cariri, it was 54.93 $\mathrm{mg} / \mathrm{g}$ (Figure 3).

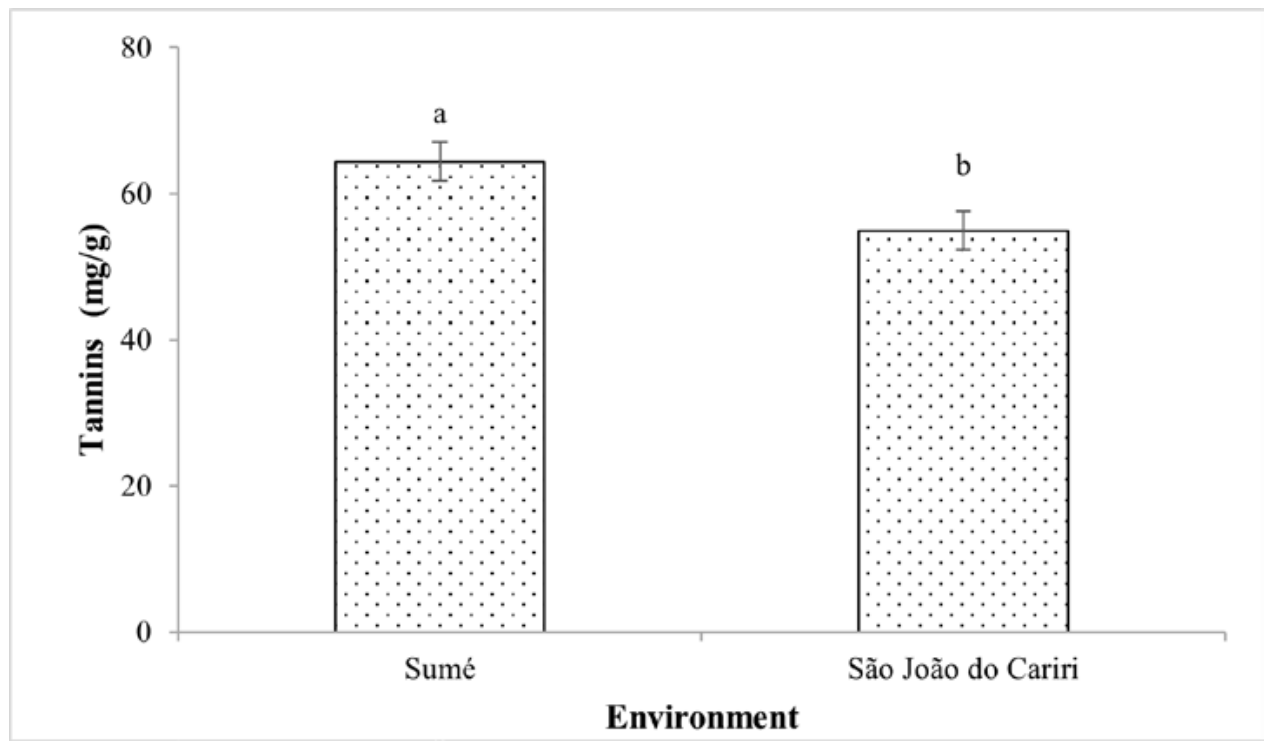

Figure 3. Tannin production in adult specimens of Sideroxylon obtusifolium, in two areas in the Cariri region of Paraíba (Semi-arid Brazil) 
The phenolic profiles of plant tissues are known to be affected by many factors, such as genotype, environment, growth stage, harvest time, process and storage conditions, and method of analysis (Vagiri et al., 2015). Changes in the content of tannins and flavonoids, combined with antioxidant activities, occur depending on the harvest month, temperature, and cultivation region. The growth factor also results in clearly different samples (Ahmed et al., 2017).

Different of plant phenophases as well as precipitation levels significantly influence the levels of release of active principles. Variations in phenolic contents were recorded and indicated as a possible product of specific stages of the plant or ecological characteristics of environments in leaves of Tournefortia paniculata cham (MORAES et al., 2007), as well as edaphic and climatic parameters evaluated over a year, including the wet and dry season in Stryphnodendron adstringens (Mart.) Coville and Stryphnodendron polyphyllum (Mart.) Coville (Jacobson et al., 2005).

An inverse correlation was observed between phenological data and production of tannins when relating these parameters, and the production of tannins and fruit production had the highest correlation $(-7.5 ; \mathrm{P}=0.04)$. All reproductive phenological parameters were positively correlated with each other. There was no significant correlation between the production of leaves and the other reproductive phenophases, as well as for the production of tannins (Figure 4).

The Figure 5 shows the factor loading of each parameter evaluated, informing the potential for correlation of each parameter with the data set. The correlation of leaf production with the other parameters was neutral, so this factor was excluded from the clustering. The other factors were clustered at a single level due to the high correlation between them.

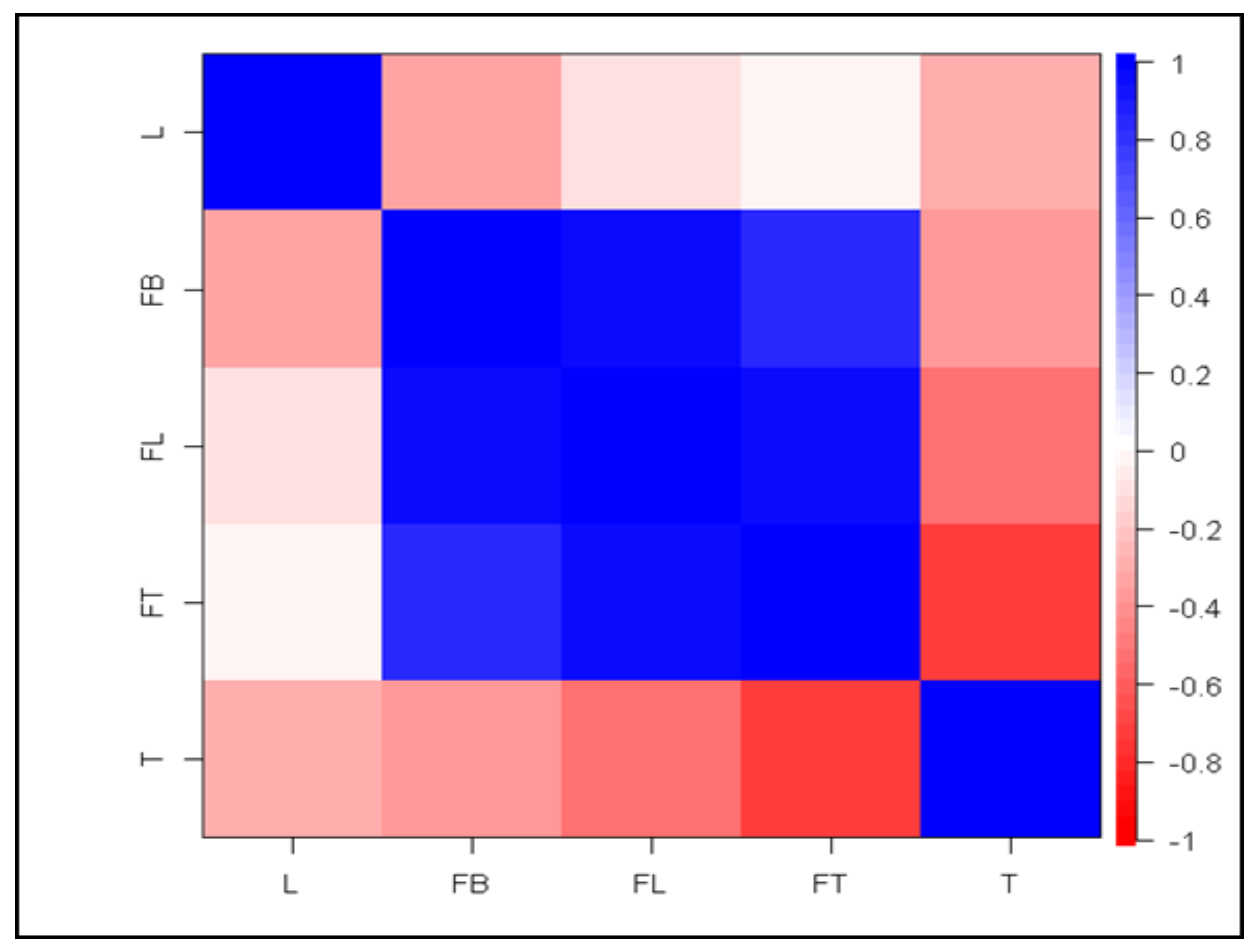

Figure 4. Correlation between different phenophases and tannin production in Sideroxylon obtusifolium. L: leaves, FB: floral bud, FL: flowering; FT: fruiting, T: Tannins 


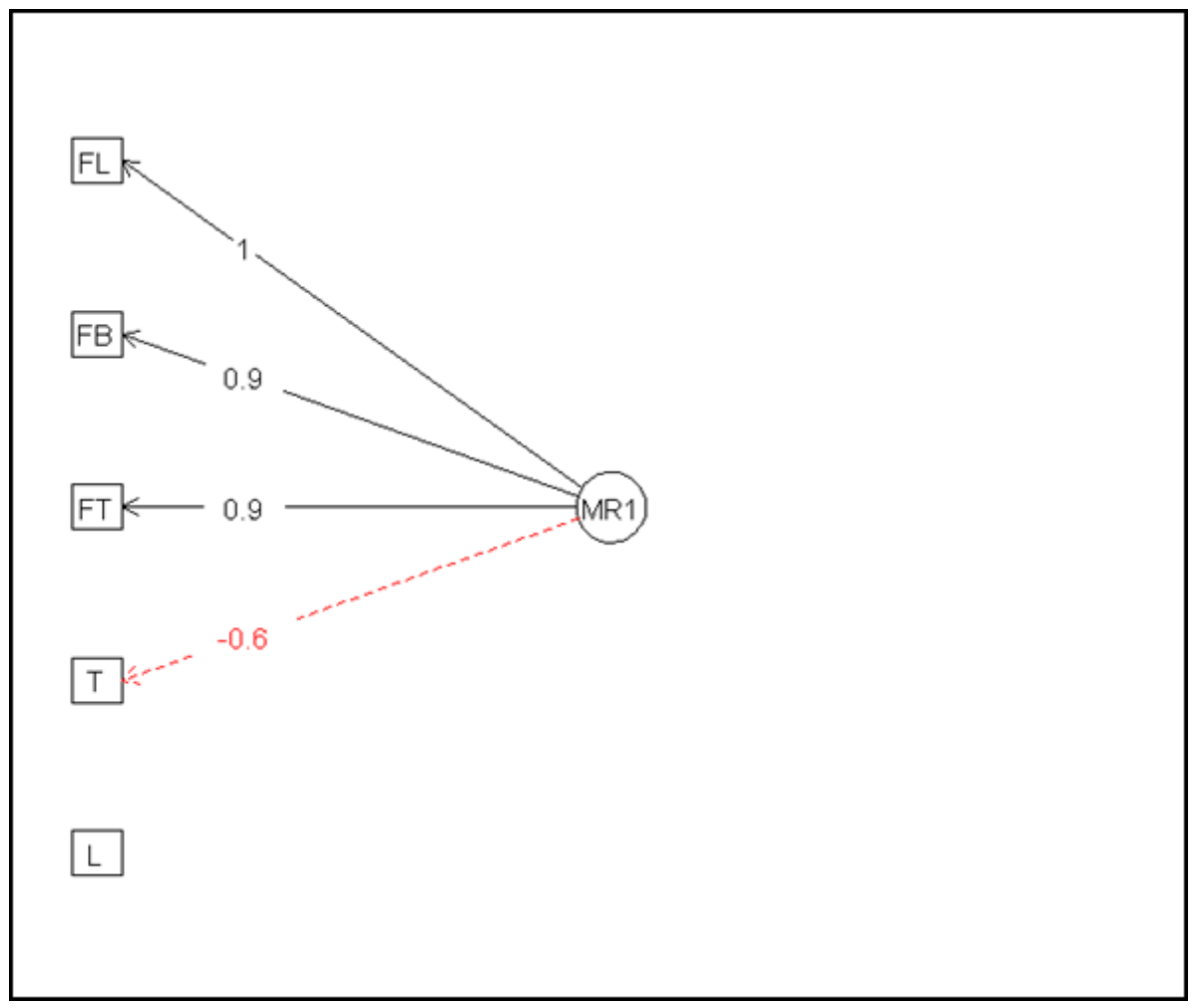

Figure 5. Factorial analysis diagram with the variables that make up the factor (MR1) and their respective factorial loads. L: leaves, FB: floral bud, FL: flowering; FT: fruiting, T: Tannins

Therefore, the data showed that the lower the annual reproductive phenological intensity, the higher the tannin production in S. obtusifolium. Thus, targeted collection of tannins should be performed in specimens with low reproductive intensity, which does not necessarily mean high vegetative intensity, as this later one had a correlation close to neutrality with all evaluated parameters.

Gomes et al. (2021) demonstrated through analytical validation and quantification how much tannins are influenced by ecological parameters and for extraction technology, highlighting the importance of seeking environmental standards to obtain raw materials within quality control standards. The authors also emphasize the importance of studies focused on the aerial part of the plants, since this has a much higher tannin concentration than the stem periderm of the S. obtusifolium, as in addition to its greater efficacy it will also contribute to the sustainable use of the species by not damage the plant through the removal stem periderm which is highly used by traditional communities. Therefore, the data indicate the phenophase in which the specimens present the highest concentration of tannins, giving support to the collection of raw material for plant drugs.

\section{CONCLUSIONS}

S. obtusifolium presents different phenological behavior in the two studied environments, confirmed mainly by the difference of the low synchrony index between each environment.

The production of tannins was also influenced by the collection region, showing an inverse correlation with reproductive phenology, especially with fruiting, indicating that the more intense the period of this phenophase, the lower the concentration of tannins in the species.

The data showed the occurrence of populations with different behaviors and provided support for the managed collection of S. obtusifolium, indicating the period for collection fruits, and raw material for extract tannins for medicinal purposes in the semi-arid region of Paraíba. 


\section{SUBMISSION STATUS}

Received: 8 Apr. 2021

Accepted: 7 Oct. 2021

Associate editor: Rodrigo Studart Corrêa (1)

\section{CORRESPONDENCE TO}

\section{Azenate Campos Gomes}

Universidade Federal da Paraíba, Conj. Pres. Castelo Branco III, CEP 58059-900, João Pessoa, PB, Brasil

e-mail: azenatecampos@gmail.com

\section{AUTHORS' CONTRIBUTIONS}

Azenate Campos Gomes: Conceptualization (Equal); Data curation (Equal); Formal analysis (Equal); Funding acquisition (Equal); Investigation (Equal); Methodology (Equal); Project administration (Equal); Software (Equal); Validation (Equal); Writing-original draft (Equal); Writingreview \& editing (Equal).

Fabricio Havy Dantas de Andrade: Methodology (Equal); Supervision (Equal).

Alecksandra Vieira de Lacerda: Conceptualization (Equal); Data curation (Equal); Formal analysis (Equal); Methodology (Equal); Project administration (Equal); Resources (Equal); Supervision (Equal); Validation (Equal); Visualization (Equal); Writing-review \& editing (Equal)

Rui Oliveira Macêdo: Conceptualization (Equal); Data curation (Equal); Formal analysis (Equal); Funding acquisition (Equal); Methodology (Equal); Project administration (Equal); Resources (Equal); Validation (Equal); Writing-review \& editing (Equal)

\section{REFERENCES}

Aesa. Agencia natural das águas Nacional da Águas. Tabelas de dados da estação de Sumé. Acesso em 01 de setembro de 2018. Disponível em: http://pcd.aesa.pb.gov.br/?command=RTMCescreen=Tabela_Sume.

Ahmed ZB, Yousfi M, Viaene J, Dejaegher B, Demeyer K, Mangelings $\mathrm{D}$ et al. Seasonal, gender and regional variations in total phenolic, flavonoid, and condensed tannins contents and in antioxidant properties from Pistacia atlantica ssp. leaves. Pharmaceutical biology 2017; 55(1): 1185-1194.

Alencar JDC, Almeida RAD, Fernandes NP. Fenologia de espécies florestais em floresta tropical úmida de terra firme na Amazônia Central. Acta amazônica 1979; 9(1): 163-199.

Alencar JC. Fenologia de cinco espécies arbóreas tropicais de Sapotaceae correlacionadas a variáveis climáticas na Reserva Ducke, Manaus, AM. Acta Amazonica 1994; 24(1): 161-182.

Alves JJA, Araújo MA, Nascimento SS. Degradação da Caatinga: Uma Investigação Eco geográfica. Revista Caatinga 2009; 22(3): 126-135.
Augspurger CK. "Phenology, flowering synchrony, and fruit set of six neotropical shrubs". Biotrópica 1983; 15(1): 257-267.

Barbosa DCDA, Alves JLDH, Prazeres SDM, Paiva AMA. Dados fenológicos de 10 espécies arbóreas de uma área de caatinga (Alagoinha-PE). Acta Botânica Brasílica 1989; 3(2): 109-118.

Barbosa DCA, Barbosa MCA, Lima LCM. Fenologia de espécies lenhosas da Caatinga. In: Leal IR, Tabarelli M, Silva, JMC, editores. Ecologia e conservação da Caatinga. Recife: UFPE; 2003.

Batalha MA, Martins FR. Reproductive phenology of the cerrado plant community in Emas National Park (central Brazil). American Journal of Botany 2004; 52(1): 149-161.

Carneiro CE, Araujo AA, Almeida Jr EB, Araujo MHT. Sapotaceae in Lista de Espécies da Flora do Brasil. Rodriguésia 2015; 66(4): 1085-1113.

Farias RC, Lacerda AV, Gomes AC, Barbosa FM, Dornelas CSM. Riqueza florística em uma área ciliar de Caatinga no Cariri Western da Paraíba, Brasil. Revista Brasileira de Gestão Ambiental e Sustentabilidade 2017; 4(7): 109-118.

Fournier, L. A. Un metodo cuantitativo para la medición de características fenológicas en arboles. Turrialba 1974; 24(4): 422-423.

Freitas LJ, Lima RB, Barbosa Filho MN, Castro PC, Júnior FDOC. Fenologia reprodutiva de cinco espécies arbóreas em ecossistema de terra firme na Amazônia Brasileira. Amazonian Biota 2015; 5(2): 38-44.

Gomes AC, Andrade FHD, Lacerda AV, Macêdo RO. Reproductive phenology in the standardization of tannins in plant drugs of specimens of Sideroxylon obtusifolium (Roem. \& Schult.) TD Penn. Brazilian Journal of Botany 2021; 44(1):561-573.

Gomes R. Fenologia reprodutiva de quatro espécies de Sapotaceae na restinga de Maricá, RJ. Revista Brasileira de Botânica 2008; 31(4): 679-687.

Gomes R, Pinheiro MCB, Lima HAD, Santiago-Fernandes LDR. Floral biology of Manilkara subsericea and Sideroxylon obtusifolium (Sapotaceae) in restinga. Brazilian Journal of Botany 2010; 33(2): 271-283.

Jacobson, TKB, Garcia J, Santos, CS, Duarte JB, Farias JG, Kliemann HJ. Influência de fatores edáficos na produção de fenóis totais e taninos de duas espécies de barbatimão (Stryphnodendron sp.). Pesquisa Agropecuária Tropical 2005; 35(3): 163-169.

Kicel A, Owczarek A, Kapusta P, Czepas JK, Olszewska MA. Contribution of individual polyphenols to antioxidant activity of Cotoneaster bullatus and Cotoneaster zabelii leaves-Structural relationships, synergy effects and application for quality control. Antioxidants 2020; 9(1): 69.

Kill LH, Martins CTVD, Silva PP. Biologia reprodutiva de Sideroxylon obtusifolium (Roem. \& Schult.) TD Penn. (Sapotaceae) na região semiárida da Bahia. Revista árvore 2014; 38(6): 1015-1025.

Koebsch F, Sonnentag O, Järveoja J, Peltoniemi M, Alekseychik P, Aurela $\mathrm{M}$, et al. Refining the role of phenology in regulating gross ecosystem productivity across European peatlands. Global change biology 2020; 26(2): 876-887.

Lacerda AV, Barbosa FM. Fitossociologia de Vegetação ArbustivoArbórea de uma Área Ribeirinha, Semiárido Paraibano, Brasil. Gaia Scientia 2018; 12(2): 34-43. 
Lacerda AV, Barbosa FM . Riparian Vegetation Structure in a Conservation Unit in the Semi-Arid Region of Paraíba, Brazil. Floresta e Ambiente 2020; 27(1): 1-10.

Lieth H, Schultz G, Contribuitions from biometeorological workshops focusing on seasonality. Journal of Biogeography 1976; 3(1): 229-230.

Lima BGD, Coelho MDFB. Fitossociologia e estrutura de um fragmento florestal da caatinga, Ceará, Brasil. Ciência Florestal 2018; 28(2): 809-819.

Makkar HPS, Becker K. Vanillin-HCl method for condensed tannins: Effect of organic solvents used for extraction of tannins. Journal of Chemical Ecology 1993;19(4): 613-621.

Mariano GC, Morellato LPC, Almeida J, Alberton B, Camargo MGG., Torres RDS. Modeling plant phenology database: Blending near-surface remote phenology with on-the-ground observations. Ecological Engineering 2016; 91(1): 396-408.

Medeiros RM, Francisco PRM, Matos RM, Santos, D, Sousa TP. Caracterização agroclimática e aptidão de culturas para diferentes municípios e regiões da Paraíba. Agropecuária científica no Semiárido 2015; 11(2): 99-110.

Melo ML, Carneiro MC. Florística e fenologia de dez espécies do extrato arbustivo-arbóreo em torno do Apiário-Escola da Universidade Estadual de Alagoas (UNEAL). Diversitas Journal 2021; 6(1): 1748-1776.

Moraes LD, Sousa OV, Yamamoto CH. Avaliações Qualitativas e Quantitativas da Variação de Metabólitos Secundários em Tournefortia paniculata Cham (Boraginaceae). Revista Brasileira de Biociências 2007; 5(2): 1032-1034.
Nieves AL, Meave JA, Morellato LPC, Manríquez GI. Reproductive phenology of useful Seasonally Dry Tropical Forest trees: Guiding patterns for seed collection and plant propagation in nurseries. Forest Ecology and Management 2017; 393(1) 52-62.

Rathcke, B.; Lacey, E. P. Phenological Patterns of Terrestrial Plant. Journal Annual Review of Ecology, Evolution, and Systematics 1985; 16(1): 179-214.

Reséndiz JAS, García LG, Olivieri F, Ramos Jr EV. Experimental assessment of the thermal behavior of a living wall system in semi-arid environments of central Mexico. Energy and Buildings 2018; 174(1): 31-43.

Sakai S, Kitajima K. Tropical phenology: Recent advances and perspectives. Ecological Research 2019; 34(1): 50-54.

Silva ÉEDM, Paixão VHF, Torquato JL, Lunardi DG, Lunardi VO. Fruiting phenology and consumption of zoochoric fruits by wild vertebrates in a seasonally dry tropical forest in the Brazilian Caatinga. Acta Oecologica 2020; 105(1): 103553.

Silva FFS, Dantas B. Sideroxylon obtusifolium (Humb. ex Roem. \& Schult.) TD Penn. quixabeira. Embrapa Semiárido-Nota Técnica/ Nota Científica 2017; 2(1): 1-6.

Suepa, T, Qi J, Lawawirojwong S, Messina JP. Understanding spatiotemporal variation of vegetation phenology and rainfall seasonality in the monsoon Southeast Asia. Environmental research 2016; 147(1): 621-629.

Vagiri M, Ekholm A, Johansson E, Andersson SC, Rumpunen K. Major phenolic compounds in black currant (Ribes nigrum L.) buds: Variation due to genotype, ontogenetic stage and location. LWTFood Science and Technology 2015; 63(2), 1274-1280. 